\title{
Genotoxic responses to titanium dioxide nanoparticles and fullerene in gpt delta transgenic MEF cells An $\mathrm{Xu}^{1,2}$, Yunfei Chai ${ }^{3}$, Takehiko Nohmi ${ }^{4}$ and Tom K Hei*1,3
}

\begin{abstract}
Address: ${ }^{1}$ Center for Radiological Research, College of Physicians \& Surgeons, Columbia University, New York, New York, USA, ${ }^{2}$ Key Laboratory of Ion Beam Bioengineering, Institute of Plasma Physics, Chinese Academy of Sciences, Hefei, Anhui, PR China, ${ }^{3}$ Department of Environmental Health Sciences, Mailman School of Public Health, Columbia University, New York, New York, USA and ${ }^{4}$ Division of Genetics and Mutagenesis, National Institute of Health Science, Tokyo, Japan
\end{abstract}

Email: AnXu - anxu@ipp.ac.cn; Yunfei Chai - Yc2181@Columbia.edu; Takehiko Nohmi - nohmi@nihs.go.jp;

Tom K Hei* - tkh1@columbia.edu

* Corresponding author

Published: 20 January 2009

Particle and Fibre Toxicology 2009, 6:3 doi:10.1 186/1743-8977-6-3
Received: 5 November 2008

Accepted: 20 January 2009

This article is available from: http://www.particleandfibretoxicology.com/content/6/I/3

(c) 2009 Xu et al; licensee BioMed Central Ltd.

This is an Open Access article distributed under the terms of the Creative Commons Attribution License (http://creativecommons.org/licenses/by/2.0), which permits unrestricted use, distribution, and reproduction in any medium, provided the original work is properly cited.

\begin{abstract}
Background: Titanium dioxide $\left(\mathrm{TiO}_{2}\right)$ nanoparticles and fullerene $\left(\mathrm{C}_{60}\right)$ are two attractive manufactured nanoparticles with great promise in industrial and medical applications. However, little is known about the genotoxic response of $\mathrm{TiO}_{2}$ nanoparticles and $\mathrm{C}_{60}$ in mammalian cells. In the present study, we determined the mutation fractions induced by either $\mathrm{TiO}_{2}$ nanoparticles or $\mathrm{C}_{60}$ in gpt delta transgenic mouse primary embryo fibroblasts (MEF) and identified peroxynitrite anions (ONOO-) as an essential mediator involved in such process.

Results: Both $\mathrm{TiO}_{2}$ nanoparticles and $\mathrm{C}_{60}$ dramatically increased the mutation yield, which could be abrogated by concurrent treatment with the endocytosis inhibitor, Nystatin. Under confocal scanning microscopy together with the radical probe dihydrorhodamine I23 (DHR I23), we found that there was a dose-dependent formation of ONOO- in live MEF cells exposed to either $\mathrm{TiO}_{2}$ nanoparticles or $\mathrm{C}_{60}$, and the protective effects of antioxidants were demonstrated by the nitric oxide synthase (NOS) inhibitor, $N^{G}$-methyl-L-arginine (L-NMMA). Furthermore, suppression of cyclooxygenase-2 (COX-2) activity by using the chemical inhibitor NS-398 significantly reduced mutation frequency of both $\mathrm{TiO}_{2}$ nanoparticles and $\mathrm{C}_{60}$.
\end{abstract}

Conclusion: Our results provided novel information that both $\mathrm{TiO}_{2}$ nanoparticles and $\mathrm{C}_{60}$ were taken up by cells and induced kilo-base pair deletion mutations in a transgenic mouse mutation system. The induction of ONOO- may be a critical signaling event for nanoparticle genotoxicity.

\section{Background}

Nanoparticles are referred to a class of particles with properties distinctively different from their bulk and molecular counterparts $[1,2]$. Due to the unique electrical, thermal, mechanical, and imaging properties, manufactured nanoparticles are highly desirable to improve the quality and performance of materials in a diverse array of industrial and medical applications, ranging from biomedicine, nanoelectronics and mechanical engineering $[3,4]$. However, with the increase in large scale production of manufactured nanoparticles, the potential occupational and public exposure to manufactured nanoparticles has aroused concern because of their large surface areas and the ability to deposit in the body [5]. Thus, a comprehen- 
sive study is clearly needed to fully explore the genotoxicity of manufactured nanoparticles, which may help to better understand their deleterious health effects and create environmentally friendly and biologically relevant nanoparticles.

Among the manufactured nanoparticles, titanium dioxide $\left(\mathrm{TiO}_{2}\right)$ nanoparticles have been already in mass production for decades. In the early years, $\mathrm{TiO}_{2}$ with the usual size of $>100 \mathrm{~nm}$ is considered a poorly soluble particulate and has been widely used as an additive in the production of a white pigment, food colorant, sunscreens, and cosmetic creams by virtue of its biologically inert mess in both humans and animals [6-8]. Recent evidence, however, has suggested that nano-sized $\mathrm{TiO}_{2}$ can cause inflammatory response in airways of rats and mice, fibrosis or lung tumors in rats, and DNA damage in Chinese hamster ovary (CHO) cells, Syrian hamster embryo fibroblasts and human lymphoblastoid cells [9-12]. A significant decrease in the level of glutathione was observed in rat lung alveolar macrophage following exposure to $\mathrm{TiO}_{2}$ nanoparticles, indicating the induction of reactive oxygen species (ROS) [13]. Furthermore, exposure of human bronchial epithelial cells to $\mathrm{TiO}_{2}$ nanoparticles was shown to induce oxidative DNA damage, micronuclei formation, and increases in the levels of hydrogen peroxide $\left(\mathrm{H}_{2} \mathrm{O}_{2}\right)$ and nitric oxide (NO) [14]. Although various in vivo and in vitro studies have shown that $\mathrm{TiO}_{2}$ nanoparticles are more toxic than its larger, micron-size counterparts, the molecular mechanisms responsible for the genotoxicity in nano-sized $\mathrm{TiO}_{2}$ are not yet understood.

Compared to $\mathrm{TiO}_{2}$ nanoparticles that have been used for over half a century, fullerene $\left(\mathrm{C}_{60}\right)$ is a novel carbon allotrope, which was discovered in 1985 and consist of a polygonal structure made up solely with 60 carbon atoms. In the past few years, methods was established to considerably improve its mass production capacity [15]. Currently, $\mathrm{C}_{60}$ with spherical symmetry has aroused intense interest for its multi-functional uses in materials science and optics and is considered for a variety of biological applications, such as imaging probes and drug carriers. Although investigation of the biological properties of pure, underivatized $\mathrm{C}_{60}$ has been hampered by its low aqueous solubility, $\mathrm{C}_{60}$ is lipophilic and can be localized in the lipid-rich regions including cell membrane in vitro [16]. It has been reported that equivalent doses of an aggregated form of underivatized $\mathrm{C}_{60}$ are 3-4 orders of magnitude more toxic to human dermal fibroblasts, lung epithelial cells, and normal human astrocytes than the derivatized, highly water-soluble derivative, $\mathrm{C}_{60}(\mathrm{OH})_{24}$. The increased toxicity is thought to be mediated through ROS induced lipid peroxidation of cell membrane [17]. In accordance with these data, a study performed using the largemouth bass reveals significant lipid peroxidations in brains of this aquatic species after exposure to underivatized $\mathrm{C}_{60}$ [18]. In a recent study, Isakovic et al. confirmed the greater toxicity of $\mathrm{C}_{60}$ in a variety of cell lines [19]. Nevertheless, there is considerable evidence that $\mathrm{C}_{60}$ induces slightly toxic in bacteria, rats, as well as in murine and human macrophages $[20,21]$. Thus, to define and constrain the potential biomedical applications of $\mathrm{C}_{60}$, it is of great interest to identify the genotoxicity of $\mathrm{C}_{60}$ in mammalian cells.

In the present study, we assessed the genotoxicity of $\mathrm{TiO}_{2}$ particles of different size distributions and $\mathrm{C}_{60}$ using $g p t$ delta transgenic mouse primary embryo fibroblasts (MEF) [22-24]. We investigated the mutation frequencies at both the redBA and gam loci and the contribution of endocytosis to the mutagenic process. Since oxidative stress has been widely implicated as a probable mechanism of genotoxicity for a variety of environmental mutagens that induce reactive oxygen and nitrogen species (ROS/RNS) under either endogenous or exogenous insults $[25,26]$, the contributions of peroxynitrite anions (ONOO-) and cyclooxygenase-2 (COX-2) were determined in the genotoxic response to $\mathrm{TiO}_{2}$ nanoparticles and $\mathrm{C}_{60}$. Our results provided direct evidence that both $\mathrm{TiO}_{2}$ nanoparticles and $\mathrm{C}_{60}$ induced kilobase pair deletion mutations in mammalian cells that were mediated by ONOO. Furthermore, COX-2 signaling pathway, which is essential in mediating cellular inflammation, carcinogenesis, and genomic instability, might be a critical signaling event for nanoparticle genotoxicity.

\section{Methods \\ MEF cell culture}

gpt delta transgenic mice were mated, and pregnant females were sacrificed on day 14 of the gestation period. The use of the transgenic animals and the experimental protocol were previously approved by the Columbia University Institutional Animal Care and Use Committee. The animals were treated humanely and with regard towards the alleviation of pain and suffering. The embryos were surgically removed and embryonic tissue prepared in culture according to standard procedures [27]. These cultures were grown and maintained in Dulbecco's modified Eagle's medium (Gibco-BRL) containing 15\% heat-inactivated fetal bovine serum and penicillin $(100 \mathrm{U} / \mathrm{ml})$, streptomycin $(50 \mu \mathrm{g} / \mathrm{ml})$ in a $5 \% \mathrm{CO}_{2}$ environment at $37^{\circ} \mathrm{C}$.

\section{Preparation of aqueous dispersion of $\mathrm{TiO}_{2}$ nanoparticles and $\boldsymbol{C}_{60}$}

Anatase $\mathrm{TiO}_{2}$ particles with different sizes were used in the present study. $\mathrm{TiO}_{2}$ nanoparticles with an average primary particle diameter of either $5 \mathrm{~nm}$ (99.7\% purity, referred to as $\left.\mathrm{TiO}_{2} 5 \mathrm{~nm}\right)$ or $40 \mathrm{~nm}\left(99.9 \%\right.$ purity, referred to as $\mathrm{TiO}_{2}$ $40 \mathrm{~nm}$ ) were purchased from Sigma-Aldrich (St. Louis, MO, USA) and Inframat Advanced Materials LLC (Farm- 
ington, CT, USA), respectively. We purchased the commercially available $\mathrm{TiO}_{2}$ at -325 mesh in diameter $(\geq 99 \%$ purity, referred to as $\mathrm{TiO}_{2}-325$ mesh) from Sigma-Aldrich (St. Louis, MO, USA). Pure (99.5\%) $\mathrm{C}_{60}$ (referred as to $\mathrm{C}_{60}$ ) was obtained from SES Research (Houston, TX, USA). The BET Surface Area for $5 \mathrm{~nm}, 40 \mathrm{~nm}$, and 325 mesh $\mathrm{TiO}_{2}$ was $114.1261 \mathrm{~m}^{2} / \mathrm{g} .38 .2268 \mathrm{~m}^{2} / \mathrm{g}$, and 8.9146 $\mathrm{m}^{2} / \mathrm{g}$, respectively, which was determined by ASAP 2020 Accelerated Surface Area and Porosimetry (Micromeritics, Norcross, GA 30093, USA). The above materials were used as received, and no further modifications were applied. $\mathrm{TiO}_{2}$ particles were suspended in distilled water to a desired concentration and sterilized by heating to $120^{\circ} \mathrm{C}$ for $30 \mathrm{~min} . \mathrm{C}_{60}$ suspension was prepared by longterm ( 60 days) stirring in water and sterilized by autoclaving. Before being diluted with $5 \mathrm{ml}$ tissue culture medium for cell treatment in T-25 flasks, all particles were sonicated on ice for $30 \mathrm{~min}$ to ensure a uniform suspension. For all experiments and analysis, distilled water was filtered with a $0.45 \mathrm{~mm}$ nominal pore size polycarbonate syringe filter (Millipore, MA, USA).

\section{Treatment with inhibitors}

Nystatin (Sigma-Aldrich, St. Louis, MO, USA), an endocytosis inhibitor, was diluted directly from stock solution with medium to a final concentration of $10 \mathrm{U} / \mathrm{ml}$. NGmethyl-L-arginine (L-NMMA; Molecular Probes, Inc., Eugene, OR, USA), nitric oxide synthase inhibitor, was dissolved in distilled water (10 mM stock) and filter sterilized. Stock L-NMMA was diluted with medium to a final concentration of $500 \mu \mathrm{M}$ and added to the cultures $24 \mathrm{~h}$ before particle treatment and remained in the medium or buffer throughout the treatment period. NS-398 (Cayman Chemical, Ann Arbor, MI, USA), a selective inhibitor of cyclooxygenase-2 (COX-2), was dissolved in dimethyl formamide to a desired stock concentration. Stock NS-398 solution was diluted with medium to a working concentration of $50 \mu \mathrm{M}$.

\section{Cytotoxicity assay}

Cell viability was evaluated by MTT assay based on the ability of viable cells to convert a water-soluble tetrazolium salt into a water-insoluble formazan product [28]. The enzymatic reduction of the tetrazolium salt happens only in living, metabolically active cells but not in dead cells. Cultures were incubated in two-well chamber slides at a density of $5.0 \times 10^{5}$ cells per well at $37^{\circ} \mathrm{C}$ for $24 \mathrm{~h}$. Graded doses of particles were added to the culture medium and incubated for another $24 \mathrm{~h}$. At the end of the treatment period, the medium was removed and $200 \mu \mathrm{l}$ of $5 \mathrm{mg} / \mathrm{ml}$ MTT was added into each well and the cultures were incubated for another $4 \mathrm{~h}$. The supernatant was removed and $1 \mathrm{ml}$ acidic isopropanol was added to dissolve the formazan crystals. The absorbance at $570 \mathrm{~nm}$ was determined by a spectrophotometer.

\section{Genomic DNA isolation}

Genomic DNA was isolated from MEF cells using the RecoverEase $^{\mathrm{TM}}$ DNA isolation kit (Stratagene, La Jolla, CA, USA) according to the protocol developed by the supplier. Briefly, about $5.0 \times 10^{6}$ cells were transferred to a chilled Wheaton dounce tissue grinder and the homogenate obtained was filtered and centrifuged at $1100 \times \mathrm{g}$ for 12 min at $4^{\circ} \mathrm{C}$. The pellet was resuspended in digestion buffer containing RNAses (RANse-It ${ }^{\mathrm{TM}}$, Stratagene) containing proteinase $\mathrm{K}$ solution $(2 \mathrm{mg} / \mathrm{ml}$ pre-warmed to $50^{\circ} \mathrm{C}$ ). Using wide-bore pipette tips, the samples were transferred to dialysis cups floating on the surface of TE buffer $(500 \mathrm{ml})$ and dialyzed for $24 \mathrm{~h}$. The purity and concentration of DNA was checked spectrophotometrically and samples were diluted with TE buffer to a final DNA concentration of about $0.5 \mathrm{mg} / \mathrm{ml}$, and stored at $4{ }^{\circ} \mathrm{C}$ for up to 3 months prior to mutation analysis.

\section{In vitro packaging of DNA}

The $\lambda$-DNA was recovered from approximately $5 \mu \mathrm{g}$ of genomic DNA and packaged with terminase and phage proteins contained in the Transpack ${ }^{\mathrm{TM}}$ kit (Stratagene, La Jolla, CA, USA) to produce infectious $\lambda$-phages. Viable phages were infected into E. coli XL-1 Blue MRA (Stratagene, La Jolla, CA, USA), mixed with lambda-trypticase agarose and poured onto $100 \mathrm{~mm}$ plates containing $30 \mathrm{ml}$ bottom agar. Plates were incubated overnight at $37^{\circ} \mathrm{C}$. The average of rescued phages per packaging reaction was $1.8 \times 10^{6}$ in the present studies. There was no significant difference in the titers between control and exposed groups.

\section{Spi- mutation analysis}

The mutant frequencies at red/gam loci were determined by Spi- selection as described previously [24,29,30]. Briefly, packaged phages were infected into E. coli XL-1 Blue MRA (P2) (Stratagene, La Jolla, CA, USA). Infected cells were mixed with molten soft agar, poured onto lambda-trypticase agar plates and incubated at $37^{\circ} \mathrm{C}$. The plaques detected on the plates (Spi- candidates) were suspended in $50 \mu \mathrm{l}$ of SM buffer. The suspension was spotted on the two types of plates where E. coli XL-1 Blue MRA (P2) or WL95 (P2) strain was spread. The plates were incubated for $24 \mathrm{~h}$ at $37^{\circ} \mathrm{C}$. The numbers of mutants that made clear spots on both strains were counted as confirmed Spi- mutants. Mutation frequencies were calculated by comparing the titration and number of confirmed mutant plaques.

\section{Quantification of cell-particle interaction}

Based on the principle of flow cytometry technology, the sizes and the shapes of all the cells can be determined by the measurement of forward scattered (FSC) and side scattered (SSC) lights [31]. Generally, FSC is related to the cell size and the optical refraction index of the outer mem- 
brane of the cells, whereas SSC indicates surface or cellular granularity. Exponentially growing MEF cells were exposed to graded doses of particles for $24 \mathrm{~h}$. After treatment, cells were rinsed with balanced salt solution and fixed. The uptake of particles were determined by flow cytometry (Becton Dickinson, San Jose, CA) equipped with an air-cooled laser providing $15 \mathrm{~mW}$ at $488 \mathrm{~nm}$.

\section{Measurement of peroxynitrite anions (ONOO-) in particles treated cells}

DHR123 is a nonfluorescent, noncharged dye that easily penetrates cell membrane. Once inside the cell, DHR123 selectively reacts with peroxynitrite to yield rhodamine 123, a highly fluorescent compound, which subsequently accumulates in the mitochondria [32]. Exponentially growing MEF cells $\left(2 \times 10^{5}\right.$ cells $)$ grown on $35 \mathrm{~mm}$ glass bottom microwell dishes (DTC3 dishes, BiopTechs) were pretreated for $30 \mathrm{~min}$ with a $5 \mu \mathrm{M}$ dose of dihydrorhodamine 123 in ACAS buffer $(127 \mathrm{mM} \mathrm{NaCl}, 0.8 \mathrm{mM} \mathrm{KCl}$, $1.2 \mathrm{mM} \mathrm{CaCl}_{2}, 1.2 \mathrm{mM} \mathrm{KH}_{2} \mathrm{PO}_{4}, 4.4 \mathrm{mM} \mathrm{C}_{6} \mathrm{H}_{12} \mathrm{O}_{6}, 10$ $\mathrm{mM}$ HEPES, pH 7.4) at $37^{\circ} \mathrm{C}$. Graded doses of particles, with or without L-NMMA, were then added to the cultures. The fluorescence of rhodamine 123 in cultures was measured using a confocal microscope and a semi-quantitative estimation of the fluorescent signal was obtained using the composite images generated by Adobe Photoshop (Adobe Systems, Inc., San Jose, CA) as described above.

\section{Statistical analysis}

All numerical data were calculated as mean and standard deviation (S.D.) and evaluated by Student's t-test. Difference between groups was considered significant when $\mathrm{p}<$ 0.05 .

\section{Results \\ $\mathrm{TiO}_{2}$ particles and $C_{60}$ induced cytotoxicity in transgenic MEF cells}

The viability of MEF cells exposed to graded doses of either $\mathrm{TiO}_{2}$ particles or $\mathrm{C}_{60}$ was analyzed by using the MTT assay. As shown in Figure $1 \mathrm{~A}-\mathrm{C}$, exposure of MEF cells to different particle sizes of $\mathrm{TiO}_{2}$ at doses ranging from 0.1 to $30 \mu \mathrm{g} / \mathrm{mlfor} 24 \mathrm{~h}$ produced various dose response curves in cell viability. Addition of either $\mathrm{TiO}_{2} 5 \mathrm{~nm}$ or $\mathrm{TiO}_{2}-325$ mesh to the culture medium had essentially no effect on the viability of MEF cells. In contrast, treatment of MEF cells with $\mathrm{TiO}_{2} 40 \mathrm{~nm}$ resulted in a dose-dependent decrease in cell viability. The viability of MEF cells was reduced by $24 \%, 34 \%, 44 \%, 52 \%$, and $60 \%$, when the concentrations of $\mathrm{TiO}_{2}$ particles were $0.1,1,10,30$ and 60 $\mu \mathrm{g} / \mathrm{ml}$, respectively. The $\mathrm{LD}_{50}$ dose of $\mathrm{TiO}_{2} 40 \mathrm{~nm}$, which resulted in 50\% cell killing, was about $30 \mu \mathrm{g} / \mathrm{ml}$. Likewise, there was a dose-dependent decrease of cell viability of MEF cells treated with $\mathrm{C}_{60}$ at doses ranging from $0.1 \mu \mathrm{g} / \mathrm{ml}$ to $10 \mu \mathrm{g} / \mathrm{ml}$ (Figure 1D). However, there was no further decrease in cell viability with $\mathrm{C}_{60}$ concentration $>10 \mu \mathrm{g} /$ $\mathrm{ml}$.

\section{Mutation frequencies at red/gam gene loci were determined in response to either $\mathrm{TiO}_{2}$ particles or $C_{60}$ exposure}

To investigate the mutagenicity of $\mathrm{TiO}_{2}$ and $\mathrm{C}_{60}$ in the $g p t$ delta assay, a Spi- mutation assay was used to determine the mutation frequencies induced by either $\mathrm{TiO}_{2}$ or $\mathrm{C}_{60}$ exposure for 3 days in transgenic MEF cells. The average number of spontaneous $\mathrm{red} / \mathrm{gam}$ gene mutants per $10^{6}$ recovered plaques in MEF cells used for these experiments was $5.69 \pm 1.87$. In cells treated with a dose of $0.1 \mu \mathrm{g} / \mathrm{ml}$ $\mathrm{TiO}_{2} 5 \mathrm{~nm}$, there was a 2.2-fold increase in mutation yield above the background (Figure 2A). However, with further increase in the concentration of $\mathrm{TiO}_{2} 5 \mathrm{~nm}$, there was no further increase in mutant yield. In contrast, treatment of MEF cells with $\mathrm{TiO}_{2} 40 \mathrm{~nm}$ resulted in a dose-dependent induction of mutation yield atthe red/gam gene locus (Figure 2B). A significant increase in mutation yield over the background level was observed at $\mathrm{TiO}_{2} 40 \mathrm{~nm}$ at concentrations $\geq 0.1 \mu \mathrm{g} / \mathrm{ml}(\mathrm{p}<0.05)$. The mutant fraction in cells treated with a dose of $10 \mu \mathrm{g} / \mathrm{ml}$ of $\mathrm{TiO}_{2} 40 \mathrm{~nm}$ was 2.7-fold higher than background. In contrast, the mutation yield at the red/gam gene locus was not much altered by $\mathrm{TiO}_{2}-325$ mesh at doses ranging from $0.1 \mu \mathrm{g} / \mathrm{ml}$ to 30 $\mu \mathrm{g} / \mathrm{ml}$ (Figure 2C). A clear dose-dependent induction of mutation at the red/gam gene locus was observed when MEF cells were subject to $\mathrm{C}_{60}$ treatment at doses ranging from $0.1 \mu \mathrm{g} / \mathrm{ml}$ to $30 \mu \mathrm{g} / \mathrm{ml}$ (Figure 2D). There was a 2.6fold increase in the mutation yield in cells treated with $\mathrm{C}_{60}$ at a concentration of $10 \mu \mathrm{g} / \mathrm{ml}(\mathrm{p}<0.05)$. These results indicated that $\mathrm{TiO}_{2}$ nanoparticles and $\mathrm{C}_{60}$ were able to produce deletion mutations in $g p t$ delta transgenic mutation assay system.

\section{Quantification of $\mathrm{TiO}_{2}$ particles and $\mathrm{C}_{60}$ uptake}

The elastically scattered light from cells/tissues provides a convenient and non-invasive approach to monitor morphological parameters and structural modifications of cells/tissues. The relative intensity of forward scattered (FSC) and the side scattered (SSC) light from single cell is often used in flow cytometry for qualitative measurement of size and granularity of cells. There were significant increases in cellular granularity induced by different particle size of $\mathrm{TiO}_{2}$ in an exponentially, dose-dependent manner (Figure $3 \mathrm{~A}-\mathrm{C}$ ). However, it was difficult to quantify $\mathrm{C}_{60}$ uptake. These results were consistent with the findings that $\mathrm{TiO}_{2}$ particles were taken into phagosomes while $\mathrm{C}_{60}$ was difficult to visualize under the electronic microscopy [33]. 


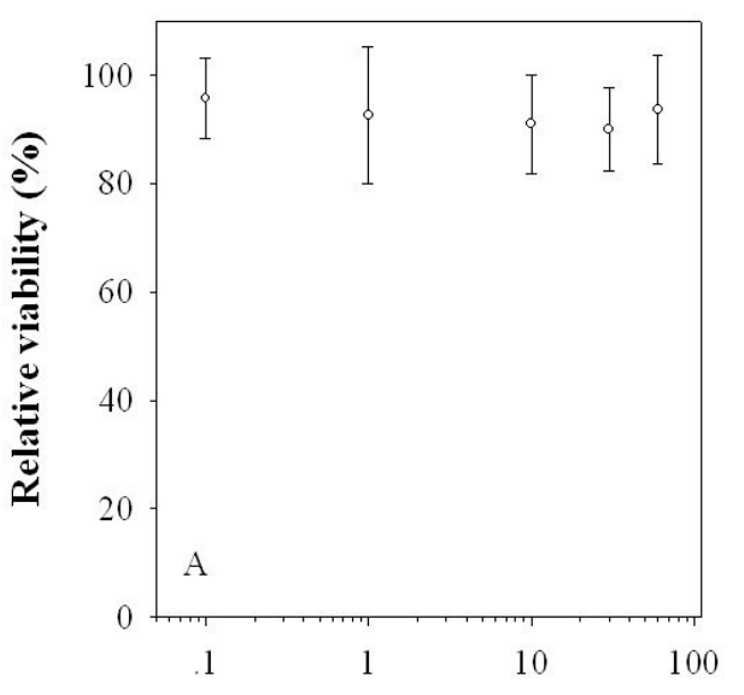

Concentrations of $\mathrm{TiO}_{2} 5 \mathrm{~nm}(\mu \mathrm{g} / \mathrm{ml})$

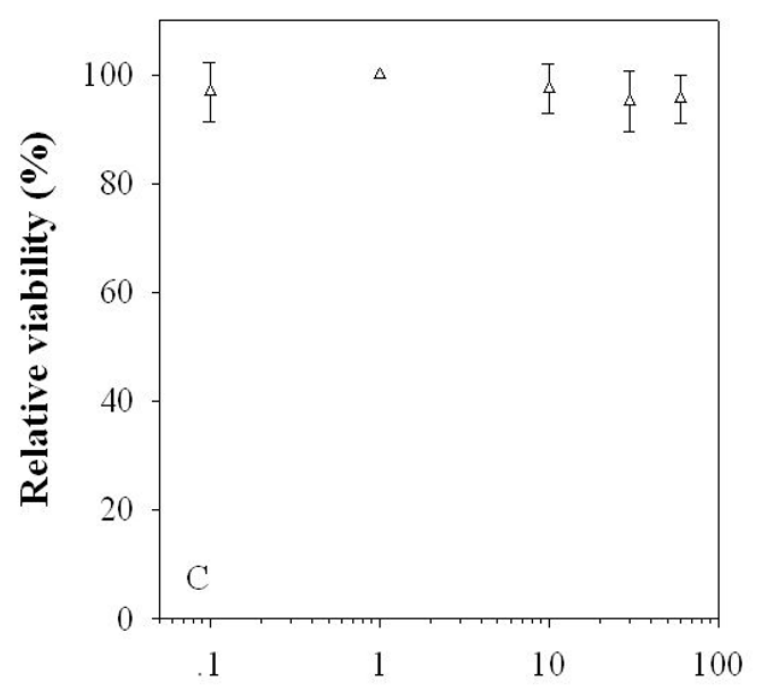

Concentrations of $\mathrm{TiO}_{2}-325$ mesh $(\mu \mathrm{g} / \mathrm{ml})$

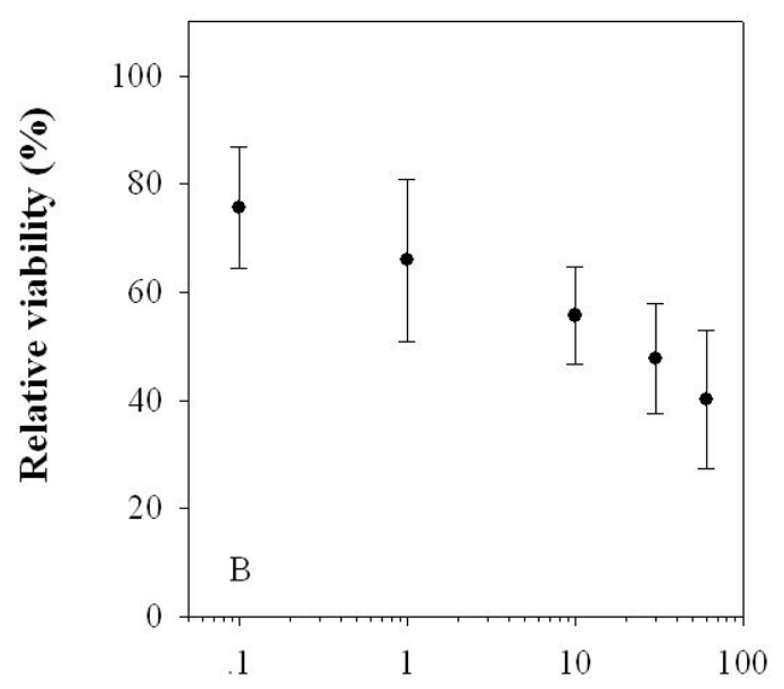

Concentrations of $\mathrm{TiO}_{2} 40 \mathrm{~nm}(\mu \mathrm{g} / \mathrm{ml})$

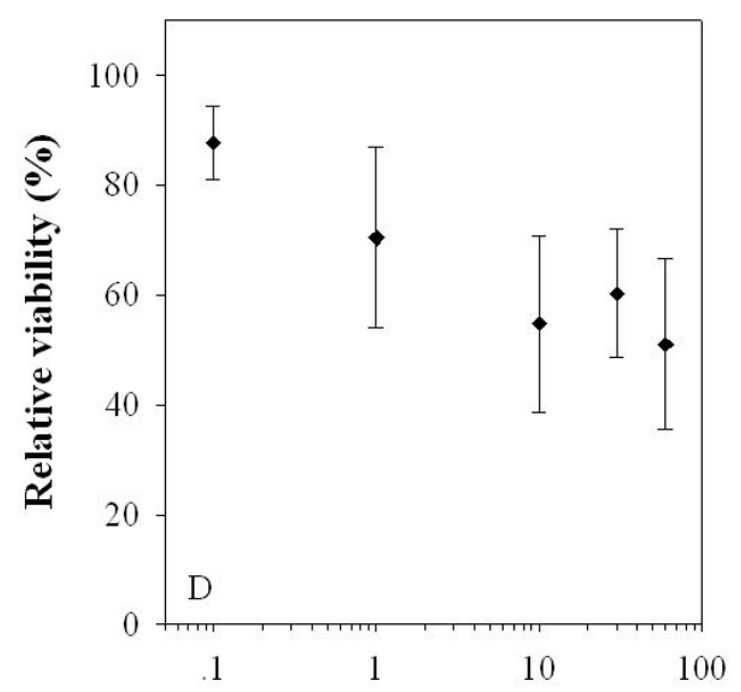

Concentrations of $\mathrm{C}_{60}(\mu \mathrm{g} / \mathrm{ml})$

Figure I

Cell viability of transgenic MEF cells treated with graded doses of $\mathrm{TiO}_{2}$ particles and $\mathrm{C}_{60}$ for $24 \mathrm{~h}$. Data were the average of three independent experiments. Bar: \pm SD.

Effect of endocytosis inhibitor on $\mathrm{TiO}_{2}$ particles and $\mathrm{C}_{60}$ induced genotoxicity in MEF Cells

To determine the particle uptake effect on the genotoxicity of either $\mathrm{TiO}_{2}$ particles or $\mathrm{C}_{60}$, Nystatin, an endocytosis inhibitor which disrupts internalization via caveolae, was used in the present experiments [34]. As shown in Figure 4, the Spi- mutant yields in MEF cells induced by either $\mathrm{TiO}_{2} 5 \mathrm{~nm}, \mathrm{TiO}_{2} 40 \mathrm{~nm}$ or $\mathrm{C}_{60}$ at a concentration of $10 \mu \mathrm{g} /$ $\mathrm{ml}$ were suppressed in the presence of $10 \mathrm{U} / \mathrm{ml}$ Nystatin by 1.6-fold, 1.8-fold and 2.2-fold, respectively. However, the presence of Nystatin had no effect on the mutation yield induced by $\mathrm{TiO}_{2}-325$ mesh treatment. The dose of Nystatin used in these experiments was non-cytotoxic nor mutagenic. 

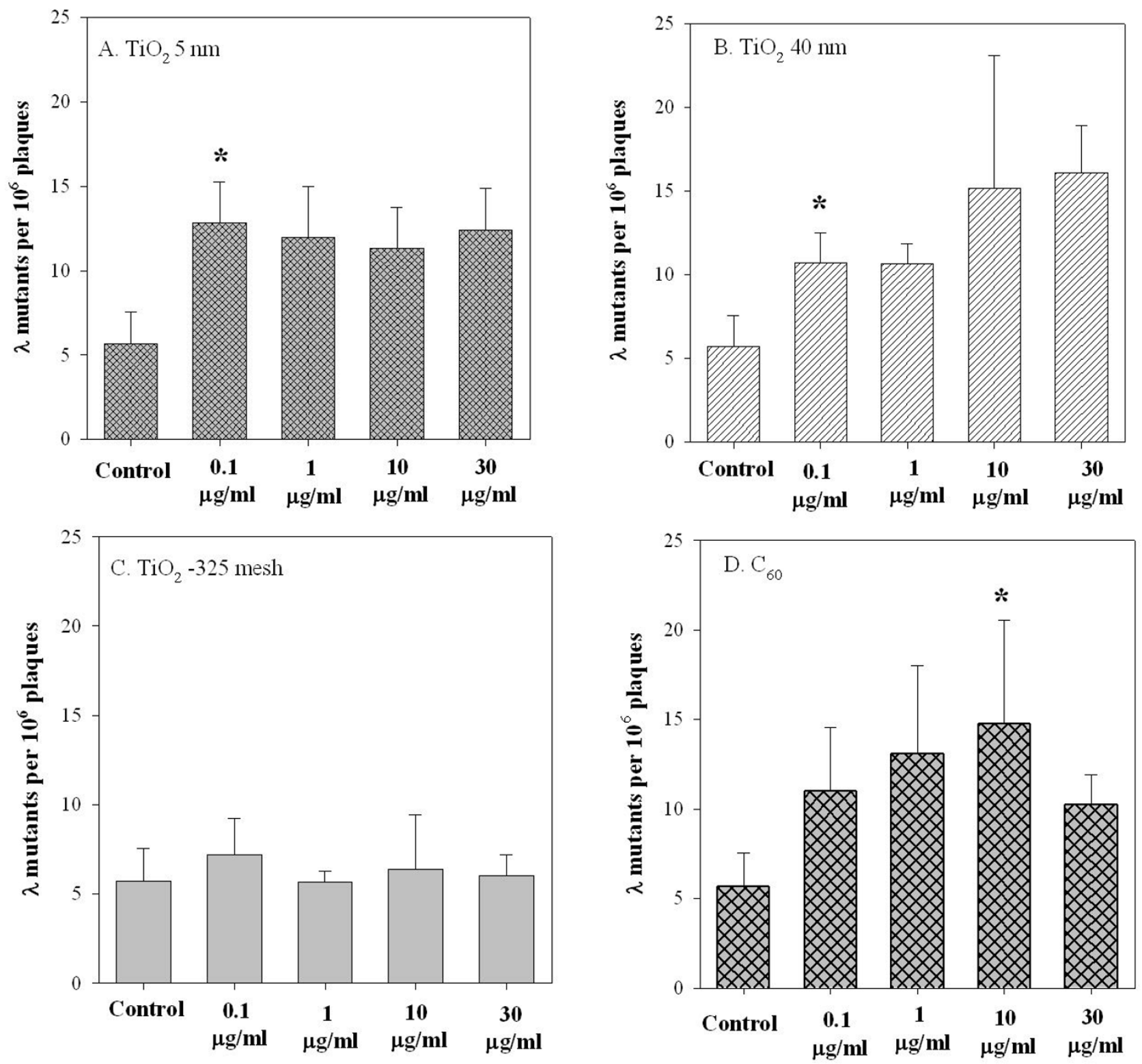

Figure 2

Mutagenic potential of different particle sizes of $\mathrm{TiO}_{2}$ and $\mathrm{C}_{60}$ at redBA and gam loci in transgenic $\mathrm{MEF}$ cells. $5 \times$ $10^{5} \mathrm{MEF}$ cells were treated with graded doses of either different particle sizes of $\mathrm{TiO}_{2}$ or $\mathrm{C}_{60}$ as described in the text. Results were expressed as the total number of confirmed $\lambda$ mutants divided by the total number of rescued phages. The average number of preexisting mutants per $10^{6}$ plaques used for these experiments was $5.69 \pm 1.87$. Data were pooled from 3 independent experiments. Bars, \pm SD. * indicated $p<0.05$.

$\mathrm{TiO}_{2}$ particles and $\mathrm{C}_{60}$ stimulated peroxynitrite anion (ONOO-) production in MEF cells

$\mathrm{ONOO}^{-}$is a strong oxidant and nitrating species resulting from the near diffusion-controlled reaction of superoxide with NO. Treatment of MEF cells with either $\mathrm{TiO}_{2} 5 \mathrm{~nm}$, $\mathrm{TiO}_{2} 40 \mathrm{~nm}$, or $\mathrm{C}_{60}$ resulted in a dose-dependent induction of ONOO- (Figure 5A, B, and 5D). The fluorescent intensity in cells treated with a $10 \mu \mathrm{g} / \mathrm{ml}$ dose of $\mathrm{TiO}_{2} 5$ nm was 1.9-fold higher than the background ( $\mathrm{p}<0.05)$ (Figure 5A). A significant increase in fluorescent intensity over the background level was observed with either $\mathrm{TiO}_{2}$ $40 \mathrm{~nm}$ or $\mathrm{C}_{60}$ at concentrations $>1 \mu \mathrm{g} / \mathrm{ml}(\mathrm{p}<0.05)$ (Figure $5 \mathrm{~B}, \mathrm{D})$. For example, the average fluorescent intensity in cells treated with either $\mathrm{TiO}_{2} 40 \mathrm{~nm}$ or $\mathrm{C}_{60}$ at a dose of 


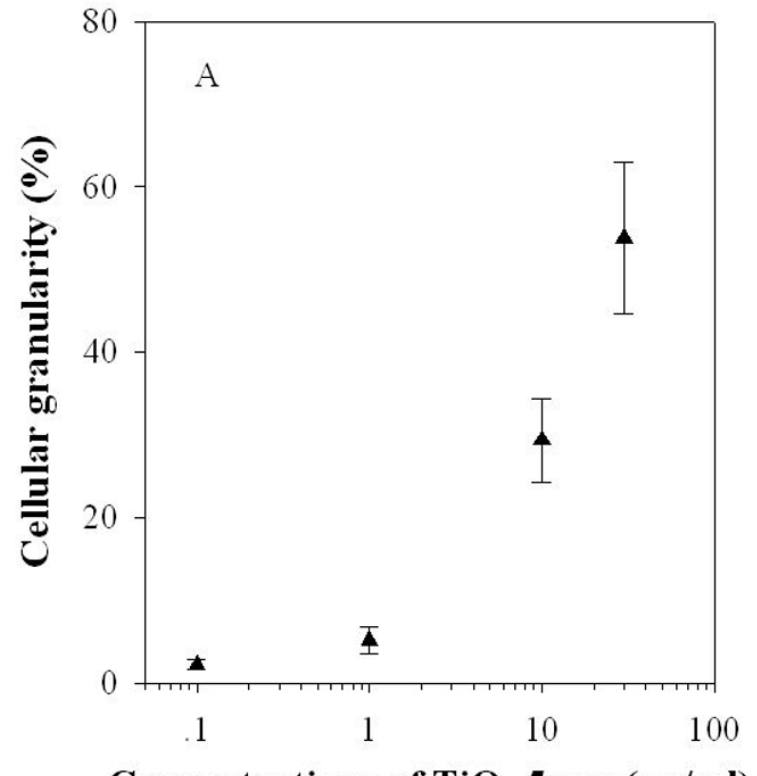

Concentrations of $\mathrm{TiO}_{2} 5 \mathrm{~nm}(\mu \mathrm{g} / \mathrm{ml})$

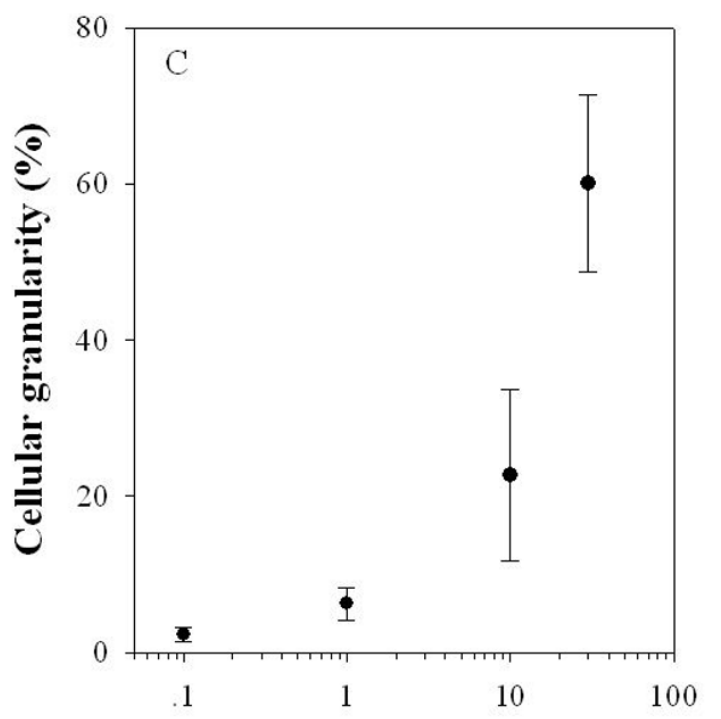

Concentrations of $\mathrm{TiO}_{2}-325 \mathrm{mesh}(\mu \mathrm{g} / \mathrm{ml})$

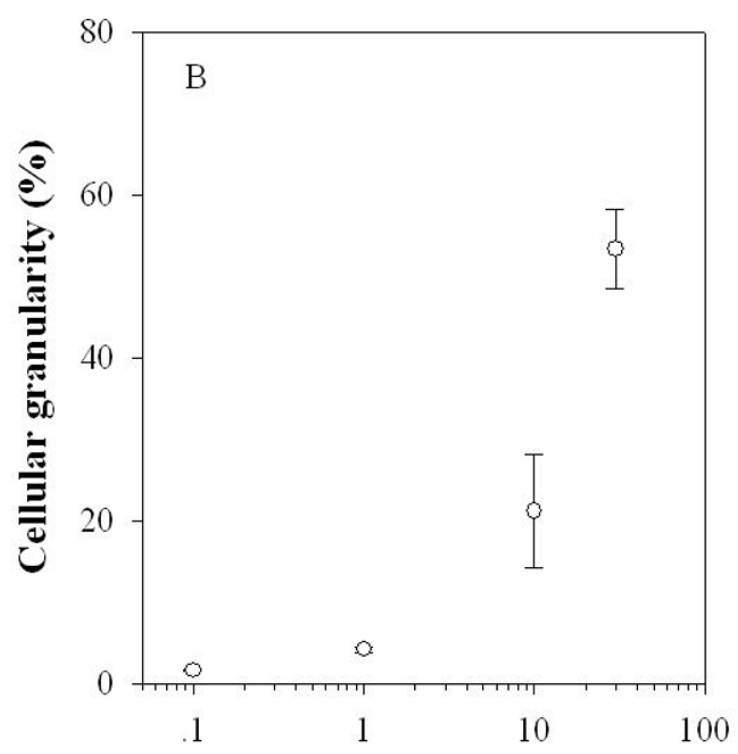

Concentrations of $\mathrm{TiO}_{2} 40 \mathrm{~nm}(\mu \mathrm{g} / \mathrm{ml})$

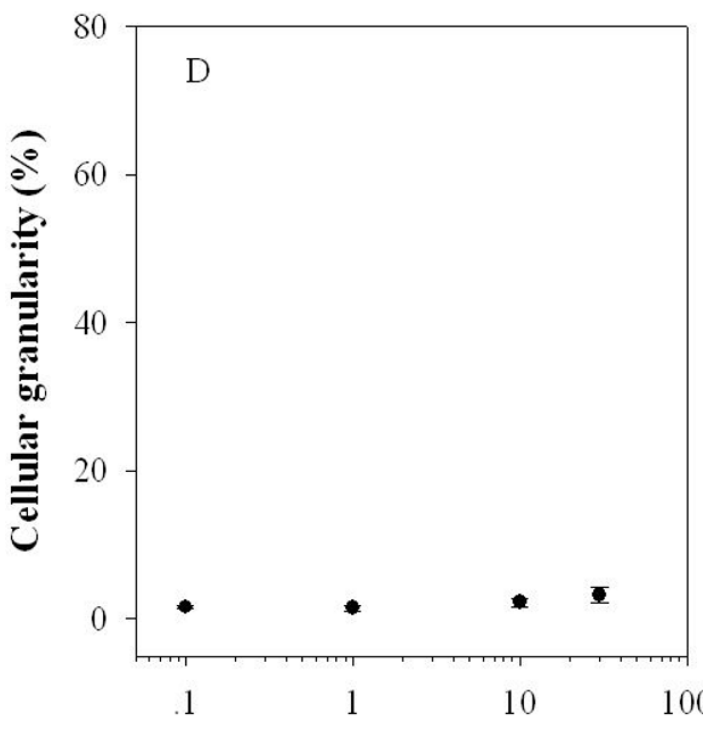

Concentrations of $\mathrm{C}_{60}(\mu \mathrm{g} / \mathrm{ml})$

\section{Figure 3}

Effect of $\mathrm{TiO}_{2}$ and $\mathbf{C}_{60}$ on the cellular granularity. MEF cells were exposed to graded doses of either different particle sizes of $\mathrm{TiO}_{2}$ or $\mathrm{C}_{60}$ for $24 \mathrm{~h}$. After treatment, cells were detected and quantified by flow cytometry. Data were pooled from 3 independent experiments. Error bars indicated S.D.

$10 \mu \mathrm{g} / \mathrm{ml}$ was 2.2-fold and 2.4-fold above nontreated cells, respectively. It should be noted that the fluorescent intensity obtained in cells treated with $\mathrm{TiO}_{2}-325$ mesh was slightly higher than the background level; however, the difference was not statistically significant (Figure 5C).

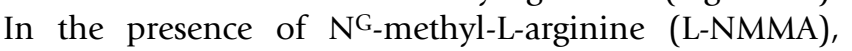

which has been shown to competitively block the activity of NOS in various cell lines, the fluorescent signals in either $\mathrm{TiO}_{2}$ nanoparticle-treated or $\mathrm{C}_{60}$-treated cells were suppressed significantly $(\mathrm{p}<0.05)$. 


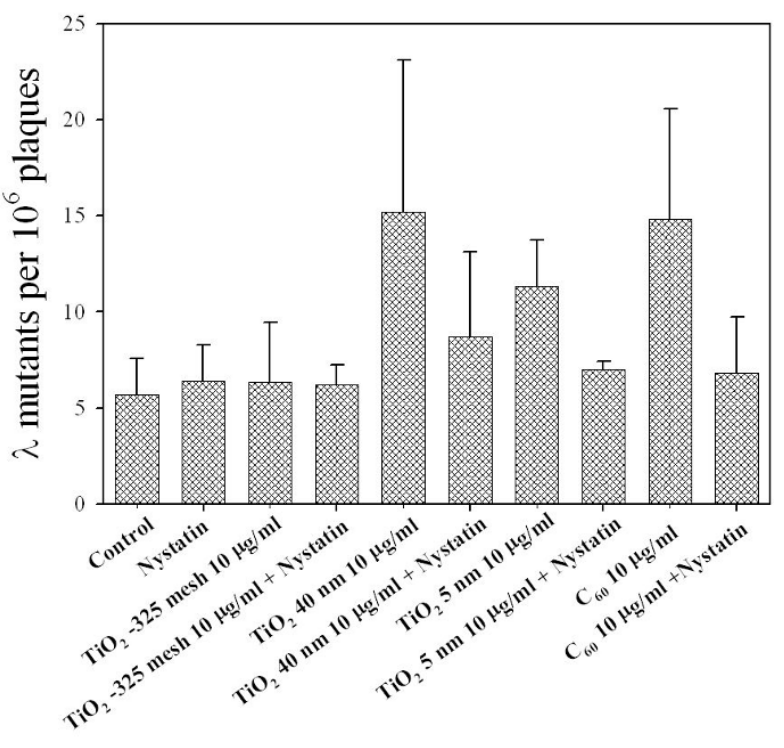

Figure 4

Mutation fractions at redBA/gam loci in MEF cells exposed to either $\mathrm{TiO}_{2}$ particles or $\mathrm{C}_{60}$ at a dose of 10 $\mu \mathrm{g} / \mathrm{ml}$ either in the presence or absence of Nystatin ( $10 \mathrm{U} / \mathrm{ml})$, an endocytosis inhibitor. Results were expressed as the total number of confirmed $\lambda$ mutants divided by the total number of rescued phages. The average number of preexisting mutants per $10^{6}$ plaques used for these experiments was $5.69 \pm$ I.87. Data were pooled from 3 independent experiments. Bars, \pm SD.

Effects of NOS inhibitor on $\mathrm{TiO}_{2}$ particles and $\mathrm{C}_{60}$-induced genotoxicity in MEF cells

The nitric oxide synthases (NOS) are hemoproteins with a cytochrome P450-like active site that catalyze the oxidation of arginine to nitric oxide and citrulline [35]. To evaluate the contribution of $\mathrm{ONOO}^{-}$in $\mathrm{TiO}_{2}$ and $\mathrm{C}_{60}$ mutagenesis, MEF cells were exposed to either $\mathrm{TiO}_{2}$ particles or $\mathrm{C}_{60}$ either in the presence or absence of L-NMMA (Figure 6). Concurrent treatment of MEF cells with either $\mathrm{TiO}_{2} 40 \mathrm{~nm}, \mathrm{TiO}_{2} 5 \mathrm{~nm}$ or $\mathrm{C}_{60}$ at a dose of $10 \mu \mathrm{g} / \mathrm{ml}$ and L-NMMA at a concentration of $500 \mu \mathrm{M}$ dramatically suppressed the mutation yield by 2.7 -fold (column 5 versus 6 ), 1.9-fold (column 7 versus 8), and 3 -fold (column 9 versus $10)$, respectively $(\mathrm{p}<0.05)$. Consistent with our previous studies, treatment of MEF cells with $\mathrm{TiO}_{2}-325$ mesh resulted in little or no Spi- mutations. Addition of LNMMA $(500 \mu \mathrm{M})$ had no effect on the overall mutation yield induced by $\mathrm{TiO}_{2}-325$ mesh (column 3 versus 4). The dose of L-NMMA used here has been shown to be nontoxic and non-mutagenic in mammalian cells. These results strongly suggested that RNS, and especially $\mathrm{ONOO}^{-}$, were causally linked to the mutagenic response of both $\mathrm{TiO}_{2}$ nanoparticle and $\mathrm{C}_{60}$ exposure.

\section{Effects of COX-2 inhibitor on $\mathrm{TiO}_{2}$ particle and $\mathrm{C}_{60^{-}}$ induced genotoxicity in MEF cells}

Nitric oxide synthase, which is critical to the biosynthesis of $\mathrm{ONOO}^{-}$, has been shown to be involved in the regulation of COX-2 expression [36]. Figure 7 showed the effect of a noncytotoxic and nonmutagenic dose of NS398, a specific inhibitor of COX-2 activity, on either $\mathrm{TiO}_{2}$ particles or $\mathrm{C}_{60}$ mutagenesis at redBA/gam loci in MEF cells. Treatment of cells with a $10 \mu \mathrm{g} / \mathrm{ml}$ dose of either $\mathrm{TiO}_{2} 40$ $\mathrm{nm}, \mathrm{TiO}_{2} 5 \mathrm{~nm}$, or $\mathrm{C}_{60}$ resulted in mutant fractions of 15.2 \pm 7.9 (column 5), $11.3 \pm 2.4$ (column 7), and $14.8 \pm 5.7$ (column 9), respectively. While NS398 treatment by itself induced no redBA/gam loci mutations, its presence in the culture medium during either $\mathrm{TiO}_{2}$ nanoparticle or $\mathrm{C}_{60}$ treatment reduced the mutant fractions by 2.2-fold, 2.8fold, and 2-fold to $7 \pm 3.1$ (column 6), $4.1 \pm 0.6$ (column 8), and $7.5 \pm 4.5$ (column 10), respectively, for the $10 \mu \mathrm{g} /$ $\mathrm{ml}$ dose treatment. In contrast, NS398 treatment had minimal effect on the mutagenic potential of $\mathrm{TiO}_{2}-325$ mesh such that there was no decrease in mutant yield in cells treated with both NS398 and $\mathrm{TiO}_{2}-325$ mesh as compared to those treated with $\mathrm{TiO}_{2}-325$ mesh alone.

\section{Discussion}

During the last few years, research on toxicologically relevant properties of manufactured nanoparticles has increased at an exponential rate. Currently, most of the toxicological work on nanoparticles have been generated with a small set of nanoparticles, such as carbon black, $\mathrm{C}_{60}, \mathrm{TiO}_{2}$, iron oxides and amorphous silica, which have been manufactured by the chemical industry for some decades and are produced in bulk quantities each year $[5,37]$. There is evidence that a number of factors are likely to contribute to the toxicity of nanoparticles, including particle number and size, surface area and charges, and chemical composition [38]. Nevertheless, experimental conditions, type or dose of nanoparticles used, or the nature of the assays can also modulate the assessment outcome. It is, therefore, necessary to establish an efficient system to determine the genotoxic events induced by nanoparticles both in vivo and in vitro.

Genetic alterations, such as point mutations, chromosomal rearrangements, recombination, and insertions or deletions of genes, are thought to be one of the earliest cellular responses caused by physical and chemical carcinogens and may play an important role in the initiation and progression of carcinogenesis [39]. Previous studies from this laboratory have shown that the gpt delta transgenic mouse system provides a unique opportunity to assess the mutagenic potential of asbestos fibers [30]. The gpt mice carry tandem repeats of $\lambda$ G10 DNA in the chromosome, which are retrievable as phage particles by an in vitro packaging reaction. The rescued phages are then used to quantify the mutation yield upon exposure to genotoxic agents. 

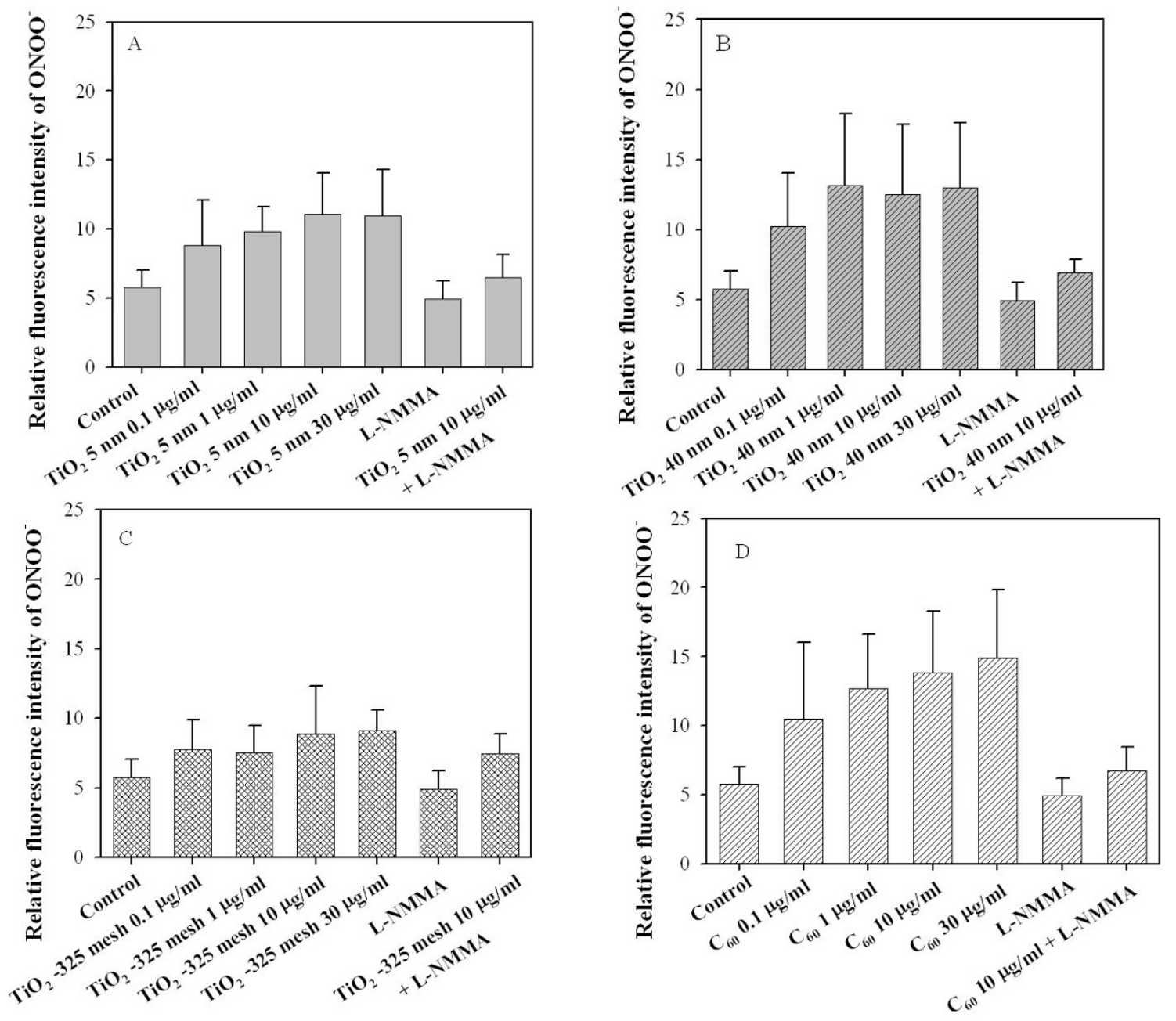

\section{Figure 5}

Generation of ONOO- in MEF cells treated with graded doses of either $\mathrm{TiO}_{2}$ particles or $\mathrm{C}_{60}$ in the presence or absence of L-NMMA at a dose of $\mathbf{5 0 0} \mu \mathrm{M}$. The fluorescence signals generated from composite images were obtained by confocal microscopy in MEF cells preloaded with dihydrorhodamine 123 with or without subsequent either $\mathrm{TiO}_{2} \mathrm{Particles}$ or $\mathrm{C}_{60}$ treatment. The relative fluorescence intensity of ONOO- in MEF cells as a function of either $\mathrm{TiO}_{2}$ particles or $\mathrm{C}_{60}$ concentration with or without L-NMMA. The relative intensities are expressed in arbitrary units. Data were pooled from three independent experiments. Bars, \pm S.D.

The Spi- selection based on deletions extending into or through both the redBA and gam genes is an efficient mutation assay system for detecting small to kilo-basesized deletions in different cells, organs, and tissues [24]. Since gene mutation, mitotic recombination, chromosome loss, and interstitial deletion largely contribute to the development of malignancy, the establishment of the gpt delta transgenic mouse mutation model may provide new insight on understanding nanoparticle-induced mutagenesis. Our present findings demonstrated that $\mathrm{TiO}_{2}$ at nano-scale increased the mutant yield at the gam and redBA loci in MEF cells, while $\mathrm{TiO}_{2}$ at micro-scale had little effect on the mutation induction. These data were consistent with several in vivo and in vitro findings that, upon transition from the micro-scale to nano-scale size range, diameter of inhaled or instilled particles are important factors influencing the toxicity response $[19,40,41]$. The BET surface area for $\mathrm{TiO}_{2} 5 \mathrm{~nm}$ was increased by 3 fold from $38.2268 \mathrm{~m}^{2} / \mathrm{g}$ to $114.1261 \mathrm{~m}^{2} / \mathrm{g}$ as compared to $\mathrm{TiO}_{2} 40 \mathrm{~nm}$, however, there was no statistically significant difference among groups expsoed to either $\mathrm{TiO}_{2} 5 \mathrm{~nm}$ or $\mathrm{TiO}_{2} 40 \mathrm{~nm}$ at the same dose (Figure 2), which are in conflict with the notion that toxic response is generally considered to be higher in particles with large surface area than those with smaller area [42]. Although a surface area dependence and correlation have been observed in instil- 


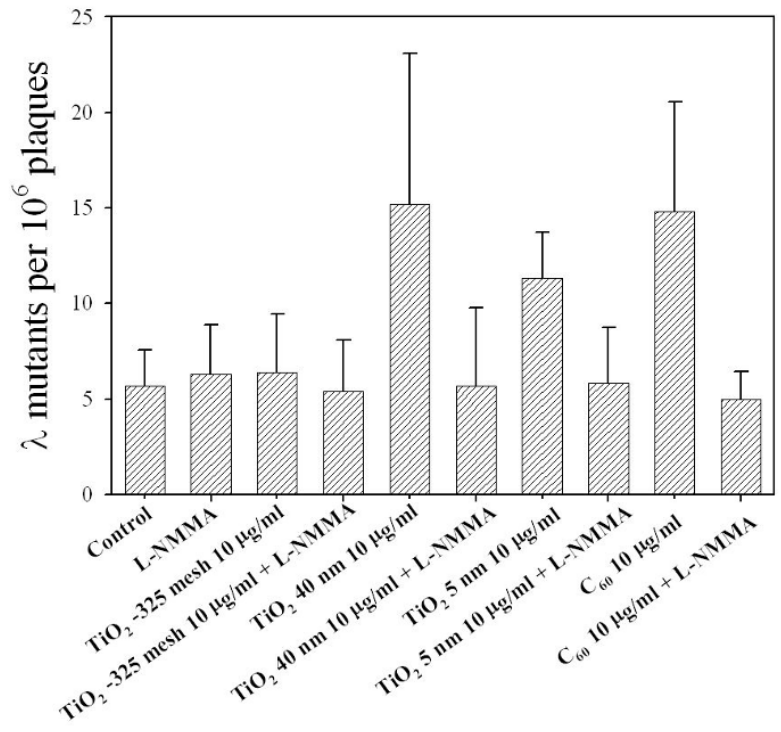

Figure 6

Mutant fractions at redBA/gam loci in MEF cells exposed to either $\mathrm{TiO}_{2}$ particles or $\mathrm{C}_{60}$ at a dose of 10 $\mu \mathrm{g} / \mathrm{ml}$ in the presence or absence of L-NMMA (500 $\mu M)$. Data were pooled from three independent experiments. Error bars indicate \pm SD.

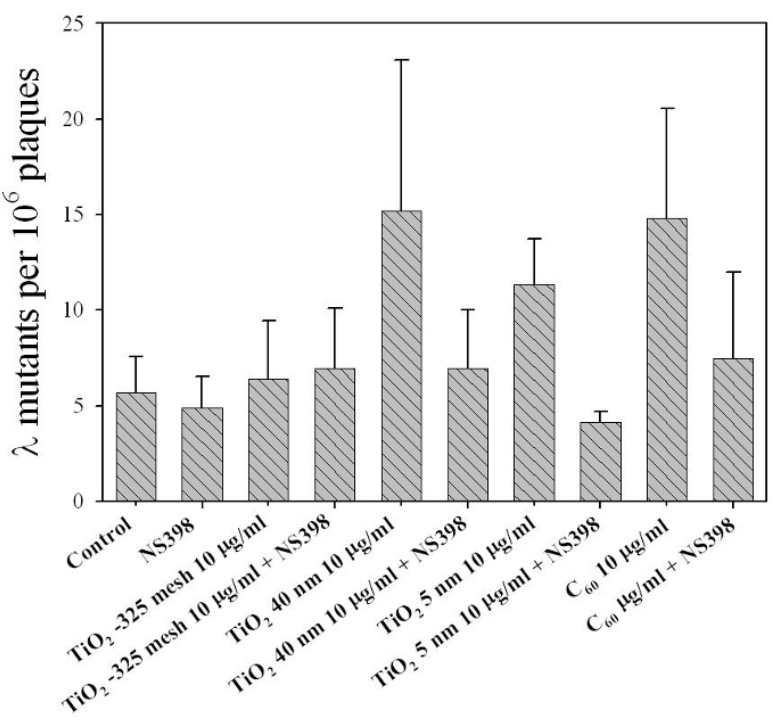

Figure 7

Mutant fractions at redBA/gam loci in MEF cells exposed to either $\mathrm{TiO}_{2}$ particles or $\mathrm{C}_{60}$ at a dose of 10 $\mu \mathrm{g} / \mathrm{ml}$ in the presence or absence of NS398 (50 $\mu \mathrm{M})$. Data were pooled from three independent experiments. Error bars indicate \pm SD. lation studies [5], recent evidence from rats and mice showed that the surface area for $\mathrm{TiO}_{2}$ nanoparticles was not a significant factor in inflammatory response $[12,43]$. In addition, we showed here that $\mathrm{C}_{60}$ was cytotoxic and mutagenic in transgenic MEF cells, although the exact mechanisms are largely unknown.

Endocytosis is a conserved process in eukaryotes by which extracellular components are taken up into cells by invagination of the plasma membrane to form vesicles that enclose these materials [44]. There are several possible uptake pathways for internalizing nanoparticles, such as phagocytosis, macropinocytosis, clathrin-mediated endocytosis, caveolae-mediated endocytosis, and clathrincaveolae-independent endocytosis $(5,45)$. Several recent evidence has shown that certain nanoparticles, such as iron oxide and silica, as well as carbon nanotubes, are internalized in cells via the endocytic pathway $[46,47]$. After $24 \mathrm{~h}$ incubation, we observed that the cellular granularity of MEF cells exposed to $\mathrm{TiO}_{2}$ particles was increased in a dose-dependant manner. In contrast, $\mathrm{C}_{60}$ had no effect on the cellular granularity, which might be due to their low contrast and small diameters. Our results with the lipid raft-disrupting agent Nystatin, which binds to cholesterol in cell membranes and disrupts the formation and trafficking of caveolae, provided further support of the idea that the endocytotic process modulated the mutagenic response of nanoparticle treatment [34]. Given $\mathrm{C}_{60}$ is lipophilic, it is possible that $\mathrm{C}_{60}$ may interact with plasma membrane lipids and exert toxicity directly in the absence of cellular uptake [18]. It is also likely that $\mathrm{C}_{60}$ interact with cell membrane receptors to trigger or alter intracellular signal transduction pathways. Due to high energetic adhesive forces close to the surface, nanoparticles are easily agglomerated to form larger particles. Thus, whether single particles or agglomerates are important in the genotoxicity of nanoparticles has not been identified yet.

The mechanism of oxidative stress induced by nanoparticles is not well understood. There is evidence that free radicals can be induced at the surface of nanoparticles such as single-wall carbon nanotube (SWCNT), semiconductor quantum dots, $\mathrm{TiO}_{2}$, environmental particles (e.g. PM$10)$, asbestos, and a range of man-made fibers $[14,48,49]$. Among the most biologically active oxyradicals such as superoxide anions $\left(\mathrm{O}_{2} \cdot\right)$, hydrogen peroxide $\left(\mathrm{H}_{2} \mathrm{O}_{2}\right)$, and hydroxyl radical $\left(\mathrm{OH}^{-}\right)$, NO is relatively long lived and catalyzed by nitric oxide synthase (NOS) [50]. The few cell culture experiments on nanoparticles, such as metal oxides and quantum dots, have identified particles within or around the mitochondria $[17,33]$. Since mitochondria constitute a major locus for the intracellular formation and reactions with $\mathrm{NO}$, it is likely that multiple radical species are involved in the genotoxic response of $\mathrm{TiO}_{2}$ 
nanoparticle and $\mathrm{C}_{60}$ exposure. $\mathrm{NO}$ reacts with $\mathrm{O}_{2}^{-\cdot}$ and can be rapidly converted into more reactive nitrogen compounds such as $\mathrm{ONOO}^{-}$that can cause nitration of proteins, hydroxylation or nitration of DNA, and mutations [51] Nano-sized $\mathrm{TiO}_{2}$ exposure has been reported to increase the production of NO and oxidative DNA damage in human bronchial epithelial cells [14]. In the present study, $\mathrm{TiO}_{2}$ nanoparticle exposure dramatically increased the generation of ONOO- in MEF cells. It should be noted that nano- $\mathrm{TiO}_{2}$ particles in the anatase crystal phase were reported to be superior catalysts and more cytotoxic as compared to the rutile particle type, which might be due to differences inherent in the crystal structures of the two phases, rather than differences in surface area (11). There is evidence that the unique structure of $\mathrm{C}_{60}$ facilitates absorption of light and transfer of this energy to triplet oxygen, thereby forming the highly reactive singlet oxygen state, which may cause oxidative damage in exposed organisms [52]. Recent reports have showed that $\mathrm{C}_{60}$ induces cytotoxic effects via the induction of reactive oxygen species in mouse cells, human cells, and fish. However, it should be noted that some data indirectly suggest that oxyradical-mediated cytoxicity of $\mathrm{C}_{60}$ might not be an inherent property of pure $\mathrm{C}_{60}$, but rather a result of the residual presence of tetrahydrofuran (THF), the organic solvent used for $\mathrm{C}_{60}$ preparation, which remains intercalated into its lattice [53]. Here, $\mathrm{C}_{60}$ suspension prepared by long-term stirring in water. The oxidation of DHR 123 by $\mathrm{ONOO}^{-}$, as detected using confocal microscopy, provided direct evidence that $\mathrm{C}_{60}$ induced a dose-dependent increase of ONOO- in single cells, which could be inhibited by the NOS inhibitor L-NMMA. Moreover, the mutation yields induced by either nano-sized $\mathrm{TiO}_{2}$ or $\mathrm{C}_{60}$ in MEF cells decreased by concurrent treatment with L-NMMA, indicating a key role of ONOO- in the mechanisms of nano-sized $\mathrm{TiO}_{2}$ and $\mathrm{C}_{60}$-induced genotoxicity. It's woth notice that the redox events might be caused by the signaling events associated with the transporting of naoparticles into the cellular structure, rather than the chemical composition/surface area combiantion of the nanoparticles.

COX-2 is a member of the COX family, which plays important roles in modulating cellular inflammation, carcinogenesis and genomic instability [39]. Nitric oxide synthase, which is critical to the biosynthesis of $\mathrm{ONOO}^{-}$, has been shown to be involved in the regulation of COX-2 expression $[36,54]$. Since COX-2 is the initial and ratelimiting enzymatic step in the metabolism of arachidonic acid into a complex group of signaling lipid mediators, the particle-induced oxidative stress may lead to transmit external signals into the cell and activate COX-2 signal pathway. In the presence of NS-398, a specific inhibitor of COX-2 [55], the genotoxic effects of both nano-sized $\mathrm{TiO}_{2}$ and $\mathrm{C}_{60}$ was reduced dramatically in MEF cells, thereby establishing the functional link for the role of ONOO- and COX-2 in mediating the genotoxic events of both nanosized $\mathrm{TiO}_{2}$ and $\mathrm{C}_{60}$.

The toxicological data specific to nanoparticles remains insufficient currently $[5,56]$. However, the potential toxicity of nanoparticles has attracted attention because of their apparent similarities to asbestos and other carcinogenic fibres/particles. Our present studies provided direct evidence on the genotoxicity of two specific types of manufactured nanoparticles, $\mathrm{TiO}_{2}$ and $\mathrm{C}_{60}$, and highlight several key health risk assessment issues associated with manufactured nanomaterial, such as the paucity of information on nanoparticle toxicology and exposure assessments as well as the extent to which nanoparticle toxicity can be extrapolated from existing particle and fiber toxicology databases.

\section{Abbreviations}

$\mathrm{TiO}_{2}$ : Titanium dioxide; $\mathrm{C}_{60}$ : Fullerene; $g p t$ : Xanthine phosphoribosyltransferase (NP 414773: GenBank); MEF: Mouse primary embryo fibroblast; DHR 123: Dihydrorhodamine 123; ONOO-: Peroxynitrite anions; $\mathrm{O}_{2}=$ Superoxide anions; COX-2: Cyclooxygenase-2; L-NMMA: $\mathrm{NG}^{\mathrm{G}}$-methyl-L-arginine; Spi-: Sensitive to P2 interference.

\section{Competing interests}

The authors declare that they have no competing interests.

\section{Authors' contributions}

XA carried out the preparation and performance of all experiments and wrote the paper. CYF assisted the Spimatation determination. NT established the gpt delta mouse mutation assay system. HTK conceived and supervised the work.

\section{Acknowledgements}

Work supported in part by grants from the National Institutes of Health ES 05786, Superfund grant ES 10349, NIEHS Center Grant ES 09089, and National Nature Science Foundation of China 20322202, 20777072.

\section{References}

I. Feynman R: There's plenty of room at the bottom. Science I99|, 254:|300-I30|.

2. National Nanotechnology Initiative: What is Nanotechnology? 2005 [http://www.nano.gov/html/facts/whatlsNano.html]. [accessed 10 November 2005].

3. Mazzola L: Commercializing nanotechnology. Nat Biotechnol 2003, 2 I ( I 0): I |37- | |43.

4. Paull R, Wolfe J, Hebert P, Sinkula M: Investing in nanotechnology. Nat Biotechnol 2003, 2 I ( I 0): I | 44- I | 47.

5. Oberdorster G, Oberdorster E, Oberdorster J: Nanotoxicology: an emerging discipline evolving from studies of ultrafine particles. Environ Health Perspect 2005, I I 3:823-839.

6. Hart GA, Hesterberg TW: In vitro toxicity of respirable-size particles of diatomaceous earth and crystalline silica compared with asbestos and titanium dioxide. J Occup Environ Med 1998, 40(I):29-42.

7. Hext PM, Tomenson JA, Thompson P: Titanium dioxide:inhalation toxicology and epidemiology. Ann Occup Hyg 2005, 49:461-472. 
8. Linden Schmidt RC, Driscoll KE, Perkins MA, Higgins JM, Maurer JK Belfiore KA: The comparison of a fibrogenic and two nonfibrogenic dusts by bronchoalveolar lavage. Toxicol Appl Pharmaco | 990, I 02(2):268-28|

9. Bermudez E, Mangum JB, Wong BA, Asgharian B, Hext PM, Warheit $D B$, Everitt Il: Pulmonary responses of mice, rats, and hamsters to subchronic inhalation of ultrafine titanium dioxide particles. Toxicol Sci 2004, 77:347-357.

10. Rahman Q, Lohani M, Dopp E, Pemsel H, Jonas L, Weiss DG, Schiffmann $D$ : Evidence that ultrafine titanium dioxide induces micronuclei and apoptosis in Syrian hamster embryo fibroblasts. Environ Health Perspect 2002, I I 0:797-800.

II. Sayes CM, Wahi R, Kurian P, Liu Y, West JL, Ausman KD, Warheit DB, Colvin VL: Correlating nanoscale titania structure with toxicity: a cytotoxicity and inflammatory response study with human dermal fibroblasts and human lung epithelial cells. Toxicol Sci 2006, 92(I): |74-185.

12. Warheit DB, Webb TR, Sayes CM, Colvin VL, Reed KL: Pulmonary instillation studies with nanoscale $\mathrm{TiO}_{2}$ rods and dots in rats: toxicity is not dependent upon particle size and surface area. Toxicol Sci 2006, 9 I:227-236.

13. Afaq F, Abidi P, Matin R, Rahman Q: Cytotoxicity, pro-oxidant effects and antioxidant depletion in rat lung alveolar macrophages exposed to ultrafine titanium dioxide. J Appl Toxicol 1998, I 8:307-312.

14. Gurr JR, Wang AS, Chen $\mathrm{CH}$, Jan $\mathrm{KY}$ : Ultrafine titanium dioxide particles in the absence of photoactivation can induce oxidative damage to human bronchial epithelial cells. Toxicology 2005, 2 I 3:66-73.

I5. Kroto HW, Heath JR, O'Brien SC, Curl RF, Smalley RE: C60: Buckminsterfullerene. Nature 1985, 318:162-163.

16. Hurt RH, Monthioux M, Kane A: Toxicology of carbon nanomaterials: Status, trends, and perspectives on the special issue. Carbon 2006, 44: 1028-1033.

17. Sayes CM, Fortner JD, Guo W, Lyon D, Boyd AM, Ausman KD, Tao YJ, Sitharaman B, Wilson LJ, Hughes JB, West JL, Colvin VL: The differential cytotoxicity of water soluble fullerenes. Nano Lett 2004, 4: |88|-|887.

18. Oberdorster E: Manufactured nanomaterials (fullerenes, C60) induce oxidative stress in the brain of juvenile largemouth bass. Environ Health Perspect 2004, I I 2: 1058-1062.

19. Isakovic A, Markovic Z, Todorovic-Markovic B, Nikolic N, VranjesDjuric S, Mirkovic M, Dramicanin M, Harhaji L, Raicevic N, Nikolic Z, Trajkovic V: Distinct cytotoxic mechanisms of pristine versus hydroxylated fullerene. Toxicol Sci 2006, 91:173-183.

20. Gharbi N, Pressac M, Hadchouel M, Szwarc H, Wilson SR, Moussa F. [60]Fullerene is a powerful antioxidant in vivo with no acute or subacute toxicity. Nano Lett 2005, 5:2578-2585.

2I. Mori T, Takada H, Ito S, Matsubayashi K, Miwa N, Sawaguchi T: Preclinical studies on safety of fullerene upon acute oral administration and evaluation for no mutagenesis. Toxicology 2006, 225:48-54.

22. Nohmi T, Katoh M, Suzuki H, Matsui M, Yamada M, Watanabe $M$ Suzuki M, Horiya N, Ueda O, Shibuya T, Ikeda H, Sofuni T: A new transgenic mouse mutagenesis test system using Spi- and 6 thioguanine selections. Environ Mol Mutagen 1996, 28(4):465-470.

23. Masumura K, Totsuka Y, Wakabayashi K, Nohmi T: Potent genotoxicity of aminophenylnorharman, formed from nonmutagenic norharman and aniline, in the liver of gpt delta transgenic mouse. Carcinogenesis 2003, 24( (12): I985-1993.

24. Nohmi T, Masumura KI: Gpt delta transgenic mouse: a novel approach for molecular dissection of deletion mutations in vivo. Adv Biophys 2004, 38:97-I2I.

25. Klaunig JE, Kamendulis LM: The role of oxidative stress in carcinogenesis. Annu Rev Pharmacol Toxicol 2004, 44:239-267.

26. O'Brien ML, Spear BT, Glauert HP: Role of oxidative stress in peroxisome proliferator-mediated carcinogenesis. Crit Rev Toxicol 2005, 35(I):6I-88.

27. Hogan B, Beddington R, Constantini F, Lacy E: Manipulating the Mouse Embryo. 2nd edition. Cold Spring Harbor, NY: Cold Spring Harbor Laboratory Press.; 1994.

28. Scudiero DA, Shoemaker RH, Paull KD, Monks A, Tierney S, Nofziger TH, Currens MJ, Seniff D, Boyd MR: Evaluation of soluble tetrazolium/formazan assay for cell growth and drug sensitivity in culture using human and other tumor cell lines. Cancer Res 1988, 48:4827-4833.
29. Shibata A, Kamada N, Masumura K, Nohmi T, Kobayashi S, Teraoka $H$, Nakagama H, Sugimura T, Suzuki H, Masutani M: Parp-I deficiency causes an increase of deletion mutations and insertions/rearrangements in vivo after treatment with an alkylating agent. Oncogene 2005, 24(8): I 328-I337.

30. Xu A, Smilenov LB, He P, Masumura K, Nohmi T, Yu Z, Hei TK: New Insight into Intrachromosomal Deletions Induced by Chrysotile in the gpt delta Transgenic Mutation Assay. Environ Health Perspect 2007, I I 5(I):87-92.

31. Stringer B, Imrich A, Kobzik L: Flow cytometric assay of lung macrophage uptake of environmental particulates. Cytometry 1995, 20(I):23-32

32. Kooy NW, Royall JA, Ischiropoulos H, Beckman JS: Peroxynitritemediated oxidation of dihydrorhodamine 123. Free Radic Biol Med 1994, 16:149-156.

33. Xia T, Kovochich M, Brant J, Hotze Matt, Sempf J, Oberley T, Sioutas C, Yeh JI, Wiesner MR, Nel AE: Comparison of the Abilities of Ambient and Manufactured Nanoparticles To Induce Cellular Toxicity According to an Oxidative Stress Paradigm. Nano Letters 2006, 6(8): I 794-I807.

34. Stuart AD, Brown TDK: Entry of feline calicivirus is dependent on clathrin-mediated endocytosis and acidification in endosomes. J Virol 2006, 80:7500-7509.

35. Park SH, Aust AE: Participation of iron and nitric oxide in the mutagenicity of asbestos in hgprt-, gpt+ Chinese Hamster V79 cells. Cancer Res 1998, 58: | |44- I | 48 .

36. Vane JR, Mitchell JA, Appleton I, Tomlinson A, Bishop-Bailey D, Croxtall ]. Willoughby DA: Inducible isoforms of cyclooxygenase and nitric-oxide synthase in inflammation. Proc Natl Acad Sci USA | 994, 9 1:2046-2050.

37. Colvin VL: The potential environmental impact of engineered nanomaterials. Nat Biotechnol 2003, 2 I: I I66-I I70.

38. Nel A, Xia T, Madler L, Li N: Toxic potential of materials at the nanolevel. Science 2006, 31 I :622-627.

39. Dixon K, Kopras E: Genetic alterations and DNA repair in human carcinogenesis. Semin Cancer Biol 2004, I 4(6):44I-448.

40. Donaldson K, Stone V, Clouter A, Renwick L, MacNee W: Ultrafine particles. Occup Environ Med 200I, 8:21 I-2I6.

4I. Nemmar A, Hoylaerts MF, Hoet PHM, Vermylen J, Nemery B: Size effect of intratracheally instilled particles on pulmonary inflammation and vascular thrombosis. Toxicol Appl Pharmacol 2003, 186:38-45

42. Pan Y, Neuss S, Leifert A, Fischler M, Wen F, Simon U, Schmid G Brandau W, Jahnen-Dechent W: Size-Dependent Cytotoxicity of Gold Nanoparticles. Small 2007, 3(I I): 1941-1949.

43. Grassian VH, O'Shaughnessy PT, Adamcakova-Dodd A, Pettibone JM, Thorne PS: Inhalation exposure study of titanium dioxide nanoparticles with a primary size of 2 to 5 nm. Environ Health Perspect 2007, I I 5(3):397-402.

44. Conner SD, Schmid SL: Regulated portals of entry into the cell. Nature 2003, 422(6):37-44.

45. Geiser M, Rothen-Rutishauser B, Kapp N, Schürch S, Kreyling W, Schulz H, Semmler M, Im Hof V, Heyder J, Gehr P: Ultrafine particles cross cellular membranes by nonphagocytic mechanisms in lungs and in cultured cells. Environ Health Perspect 2005 , I I3(I I): I555-1560.

46. Xing $X, \mathrm{He} X$, Peng J, Wang $\mathrm{K}$, Tan W: Uptake of silica-coated nanoparticles by HeLa cells. I Nanosci Nanotechnol 2005 5: I688-I693.

47. Kam NW, Liu Z, Dai H: Carbon nanotubes as intracellular transporters for proteins and DNA: an investigation of the uptake mechanism and pathway. Angew Chem Int Ed Engl 2006, 45:577-58I.

48. Shvedova AA, Castranova V, Kisin ER, Schwegler-Berry D, Murray AR, Gandelsman VZ, Maynard A, Baron P: Exposure to carbon nanotube material: assessment of nanotube cytotoxicity using human keratinocyte cells. J Toxicol Environ Health A 2003, 66:1909-1926.

49. Martin LD, Krunkosky TM, Dye JA, Fischer BM, Jiang NF, Rochelle LG, Akley $\mathrm{NJ}$, Dreher $\mathrm{KL}$, Adler KB: The role of reactive oxygen and nitrogen species in the response of airway epithelium to particulates. Environ Health Perspect 1997, 105: 1301-1307.

50. Nathan C, Xie QW: Nitric oxide synthases: Roles, tolls, and controls. Cell I994, 78(6):915-918. 
5I. Juedes MJ, Wogan GN: Peroxynitrite-induced mutation spectra of pSPI89 following replication in bacteria and in human cells. Mutat Res 1996, 349(I):5I-6I.

52. Arbogast JW, Darmanyan AO, Foote CS, Rubin Y, Diederich FN, Alvarez MM, Anz SJ, Whetten RL: Photophysical properties of C60. J Phys Chem 1991, 95:II-12.

53. Henry TB, Menn F, Fleming JT, Wilgus John, Compton RN, Sayler GS: Attributing Effects of Aqueous C60 Nano-Aggregates to Tetrahydrofuran Decomposition Products in Larval Zebrafish by Assessment of Gene Expression. Environ Health Perspect 2007, II5(7): 1059-1065.

54. Chen BC, Chen YH, Lin WW: Involvement of p38 mitogenactivated protein kinase in lipopolysaccharide-induced iNOS and COX-2 expression in $\mathbf{J 7 4}$ macrophages. Immunology 1999, 97:124-129.

55. Barnett J, Chow J, Ives D: Purification, characterization and selective inhibition of human prostaglandin $\mathbf{G} / \mathbf{H}$ synthase I and 2 expressed in the baculovirus system. Biochim Biophys Acta 1994, I 209:130-139.

56. Borm PJA, Robbins D, Haubold S, Kuhlbusch T, Fissan H, Donaldson K, Schins R, Stone V, Kreyling W, Lademann J, Krutmann J, Warheit $D$, Oberdorster $E$ : The potential risks of nanomaterials: a review carried out for ECETOC. Particle Fibre Toxicol 2006, 3:II-46.

Publish with Bio Med Central and every scientist can read your work free of charge

"BioMed Central will be the most significant development for disseminating the results of biomedical research in our lifetime. "

Sir Paul Nurse, Cancer Research UK

Your research papers will be:

- available free of charge to the entire biomedical community

- peer reviewed and published immediately upon acceptance

- cited in PubMed and archived on PubMed Central

- yours - you keep the copyright 